SOKOLOVA, Ja.: Konstrukcii social'noj samoidentifikacii i samoprezentacii govorjaščego: Očerki ob ègocentričeskich sredstvach slovackogo jazyka. Mauritius: Palmarium Academic Publishing, 2019. 130 s. ISBN 978-620-2-38404-9.

SOLOV’JEVA, N. V.: Sovremennyje mediateksty v aspekte stileobrazujuščich kategorij «Avtor» $i$ «Adresat»[Èlektronnyj resurs]. [cit. 23. 10. 2020]. In: Vestnik Čeljabinskogo gos. un-ta. Ser. Filologija, iskusstvovedenije, 2012, vyp. 71, № 32 (286), s. 107-111. Režim dostupa: https://cyberleninka.ru/article/n/sovremennyemediatekstyv-aspekte-stileobrazuyuschih-kategoriy-avtor-i-adresat.

ŠANSKIJ, N. M.: Frazeologija sovremennogo russkogo jazyka: učeb. posobije. 6-je izd. Moskva: Librokom, 2012. 272 s. ISBN 978-539-7023-184.

VALGINA, N. S.: Teorija teksta: učeb. posobije. Moskva: Logos, 2003. 278 s. ISBN 5-94010$-187-9$.

VINOKUR, T. G.: Govorjaščij i slušajuščij: varianty rečevogo povedenija. Moskva: Nauka, 1993. 172 s. ISBN 5-02-011563-0.

ZEMSKAJA, Ju. N. i dr.: Teorija teksta: učeb. posobije. Moskva: Flinta, 2010. 132 s. ISBN 978-5-9765-0841-5 (Flinta), 978-5-02-037163-7 (Nauka).

ŽUKOV, V.P. - ŽUKOV, A. V.: Russkaja frazeologija: učeb. posobije. 2-je izd., ispr. i dop. Moskva: Vysšaja škola, 2006. 408 s. ISBN 5-06-005399-7.

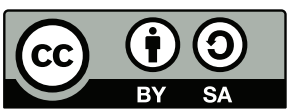

This work can be used in accordance with the Creative Commons BY-SA 4.0 International license terms and conditions (<https://creativecommons.org/licenses/by-sa/4.0/legalcode>). This does not apply to works or elements (such as images or photographs) that are used in the work under a contractual license or exception or limitation to relevant rights.

\title{
https://doi.org/10.5817/0S2020-4-9
}

\section{Sborník k nedožitým devadesátým narozeninám profesora Stanislava Žaži}

GAZDA, J. (ed.): Př́spěvky k aktuálním otázkám jazykovědné rusistiky (5): pragmatika syntax - sémantika. Brno: Jan Sojnek - Galium, 2020. 127 s. ISBN 978-80-88296-09-6.

Dne 5. srpna 2018 se uzavřela životní cesta předního českého rusisty a slavisty prof. PhDr. Stanislava Žaži, CSc. U př́ležitosti jeho 9o. narozenin ( ${ }^{*} 14.4$. 1929) uspořádal Ústav slavistiky Filozofické fakulty Masarykovy univerzity ve spolupráci a s podporou České asociace slavistů a Středoevropského centra slovanských studií dne 10. 5. 2019 jednodenní kolokvium nazvané Aktuální otázky současné jazykovědné 
rusistiky: pragmatika - syntax - sémantika. Zúčastnili se ho vedle pracovníků pořádajícího pracoviště rusisté $\mathrm{z}$ dalších slavistických pracovišť včetně hostů ze Slovenska a Ruska. Tematické zaměření kolokvia bylo zvoleno s ohledem na ty oblasti, kterým se zesnulý jubilant především zabýval: jako hlavním zaměřením syntaktik chápal větnou skladbu jako komplexní vnímání výrazové struktury výpovědi, na niž je třeba nahlížet jako na strukturu specificky spjatou jak se sémantickými, tak i s pragmatickými komponenty jazyka. Př́spěvky, které na tomto vzpomínkovém setkání zazněly, tvoři obsah tohoto sborníku a jsou řazeny obvyklým způsobem

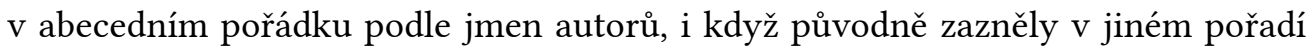
$\mathrm{v}$ malých tematických blocích.

O. L. Berger (Brno) v prŕspěvku Словосочетание и синтагма в русской и чешской грамматической традиции ${ }^{1}$ srovnává termíny „словосочетание“ а „синтагма“, jak jsou prezentovány v ruských a českých gramatikách a učebnicích syntaxe. $\mathrm{Na}$ základě analýzy obsahu těchto termínů v pracích ruských, českých a slovenských rusistů a českých bohemistů došla ke zjištění, že tyto termíny jsou odlišně chápány.

Studie J. Gazdy (Brno) Skrytá aserce jako prostréedek jazykové manipulace v současné ruské a české politické publicistice ${ }^{2}$ je zaměřena na diskurzívní analýzu titulků a perexů vybraných textů současné ruské a české politické publicistiky, v nichž je aserce (tvrzení) a její záměna za presupozici (předpoklad) využívána jako prostředek jazykové manipulace.

L. Guzi (Prešov) věnuje pozornost ve svém článku Проблематика видовременных форм русского глагол $a^{3}$ mluvnickým tvarům ruského slovesa $\mathrm{z}$ hlediska gramatické kategorie vidu a času; všímá si, jak se vyjádřený děj odráží v jejich sémantice. Kategorie vidu je v centru pozornosti řady jazykovědců, kteří však nesdílejí jednotný názor na danou problematiku. Proto autor článku považuje výzkum sémantiky vidu za téma stále aktuální.

Homonyma, nebo sémantická diferenciace? ${ }^{4}$ je zamýšlení I. Janyškové (Brno), v němž řeší otázku, zda české chytat („uchopovat, brát“) a ruské nářeční „хитать“ („kývat, viklat, houpat, kolébat“) vznikly sémantickou diferenciací z praslovanského základu, nebo jde o geneticky nepř́ibuzná homonyma. Řešení odborníků z oblasti etymologie není jednotné.

Pozornost formování terminologie managementu v současné ruštině a češtině je věnována $\mathrm{v}$ př́spěvku Latinismy a grecismy $v$ terminologii managementu ${ }^{5}$

1 GAZDA, J. (ed.): Př́spěvky k aktuálním otázkám jazykovědné rusistiky (5): pragmatika - syntax sémantika. Brno: Jan Sojnek - Galium, 2020, s. 9-19.

2 Tamtéž, s. 21-30.

3 Tamtéž, s. 31-43.

4 Tamtéž, s. $45-49$.

5 Tamtéž, s. 53-63. 
L. Mrověcové (Ostrava). Na přelomu 20. a 21. století, kdy termíny začaly do obou jazyků pronikat, měly charakter neologismů převážně anglického původu. V manažerské komunikaci v současném ruském a českém podnikatelském prostředí má velký počet těchto termínů povahu internacionalismů s latinskými a řeckým komponenty.

Z. Nedomová (Ostrava) v článku $K$ vyjadřování prostorových vztahů v ruštině $a$ češtině ${ }^{6}$ se zabývá jednou oblastí funkční gramatiky, a sice vyjadřováním lokalizace $\mathrm{v}$ prostoru. Vzpomenuty jsou práce řady jazykovědců a jejich pojetí prostorových vztahů v ruštině a češtině (namnoze v konfrontaci s dalšími jazyky). Ze studia jejich prací vyplývá, že základní funkci pro vyjádření sledovaných vztahů plní zejména prosté a předložkové pády substantiv, ale též adverbia, prefigovaná slovesa a frazeologické obraty.

Termíny řecko-latinského původu jsou součástí mnoha termínů internacionálního lexika včetně lingvistické terminologie. L. Plesník (Ostrava) ve svém pojednání Греко-латинские терминоэлементы в лингвистической терминологии (на примере русского языка) ${ }^{7}$ rozebírá problematiku řecko-latinských termínů v lingvistické terminologii současné ruštiny.

I. Pospíšil (Brno) ve své studii fazyk a literatura: problém „nové filologie 8 sumarizuje charakter brněnské lingvistické rusistiky a slavistiky. Syntetizuje závěry dvou tematických bloků, které nedávno zorganizoval pro bratislavský časopis Philologia a které se týkaly „nové filologie“ - sepětí literárněvědné a lingvistické terminologie a metodologie. Na bázi kritické komparace dochází k závěru, že vznik nového filologického celku bude pozvolný, spíš osobité srůstání než náhlý zrod nové disciplíny.

G.S. Prokudina (Brno) v příspěvku Национальная специфика концепта «война» в русской когнитивной системе 9 zoumá koncept „война“ v ruském kognitivním obrazu světa na materiálu provedeného dotazníkového zjištění. Zkoumaný materiál byl získán od cca sta respondentů různého věku, pohlaví a dosaženého vzdělání. Na základě výsledů zpracování získaného materiálu byla zjištěna specifika v pojetí konceptu „война“ v ruském kognitivním světě, v ruském řečovém vědomí.

V pojednání Синтаксический синкретизм как структурно-семантическая категория (на фоне сопоставительной славянской синтактологии) ${ }^{10}$ vуmеzuје

\footnotetext{
6 Tamtéž, s. 65-78.

7 Tamtéž, s. $79-87$.

8 Tamtéž, s. 89-99.

9 Tamtéž, s. 101-107.

10 Tamtéž, s. 111-122.
} 
S. A. Rylov (Nižní Novgorod) sémantické zásady syntaktického synkretismu v obsahovém a výrazovém plánu. Předmětem výzkumu byly ruské a české synkrety. Jako cíl svého snažení si autor stanovil provést srovnávací analýzu synkretických konstrukcí $\mathrm{v}$ ruštině a češtině, a to $\mathrm{v}$ synchronním i v diachronním pohledu. Základem srovnání byl výrazový plán.

Přehled odlišností v chápání vybraných syntaktických jevů v ruské syntaktické tradici a v teoriích českých rusistů je v centru pozornosti Z. Vychodilové (Olomouc). V článku Profesor Stanislav Žaža a česká a ruská syntaktická tradice ${ }^{11}$ se autorka soustředuje na popis odlišností $v$ pojetí větných členů $\mathrm{v}$ tzv. akademických gramatikách ruštiny a $\mathrm{v}$ autorských učebnicích a monografiích.

Vědecká, pedagogická a další akademická činnost profesora S. Žaži byla již mnohokrát při různých jubilejních př́ležitostech podrobně připomenuta a zhodnocena. Vydaný jubilejní sborník je důstojnou připomínkou jeho nedožitého životního výročí. Aleš Brandner

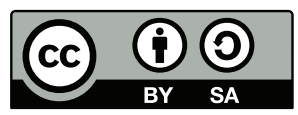

Toto dílo lze užít v souladu s licenčními podmínkami Creative Commons BY-SA 4.0 International (<https:// creativecommons.org/licenses/by-sa/4.0/legalcode>). Uvedené se nevztahuje na díla či prvky (např. obrazovou či fotografickou dokumentaci), které jsou v díle užity na základě smluvní licence nebo výjimky či omezení př́slušných práv.

https://doi.org/10.5817/OS2020-4-10

\section{Studia Slavica XXIII/2}

Studia Slavica XXIII (2019), 2, 201 s. ISSN 1803-5663.

Časopis Studia Slavica byl do roku 2017 společným vydavatelským počinem katedry slavistiky Filozofické fakulty Ostravské univerzity a univerzity v Opolí a navazoval na sborník vydávaný oběma pracovišti od roku 1993. Od roku 2002 vycházela Studia Slavica pravidelně jedenkrát ročně a od roku 2013 se ustálila na dvě čísla ročně. $\mathrm{V}$ časopise jsou publikovány původní vědecké stati z oblasti literární vědy, lingvistiky, kulturologie a translatologie, dokládající stav a vývoj v oblasti slovanské filologie. Součástí časopisu jsou také recenze, informace o nových publikacích a kronika. Již od začátku své existence procházely př́spěvky otištěné v tomto periodiku recenzním řízením. Příspěvky jsou publikovány ve všech slovanských jazycích včetně

11 Tamtéž, s. 123-127. 